\title{
The Validity and Reliability Study of Parent Report of the Childhood Executive Functioning Inventory for Preschoolers
}

\author{
Beyza Hamamcı ${ }^{1}$, İbrahim Hakkı Acar ${ }^{2}$, Gülden Uyanık ${ }^{3}$ \\ ${ }^{I}$ Department of Elementary and Early Childhood Education, Faculty of Education, Middle East Technical University, Ankara, \\ Turkey, beyza@metu.edu.tr \\ ${ }^{2}$ Department of Psychology, Faculty of Social Sciences, Ozyegin University, Istanbul, Turkey, ibrahim.acar@ozyegin.edu.tr \\ ${ }^{3}$ Department of Primary Education, Ataturk Faculty of Eduaction, Marmara University, Istanbul, Turkey, \\ guyanik@marmara.edu.tr
}

Corresponding Author: Beyza Hamamc1

Article Type: Research Article

Acknowledgement: This research was presented at "VIIth International Eurasian Educational Research Congress (EJER)" on September 10th, 2020.

To Cite This Article: Hamamc1, B., Acar, İ. H., \& Uyanık, G. (2021). The validity and reliability study of parent report of the childhood executive functioning inventory for preschoolers. Eğitimde Kuram ve Uygulama, 17(2), 1-10. doi: 10.17244/eku.884918

Ethical Note: Research and publication ethics were followed. In this study, the data were collected before 2020, and voluntary participation of study group was observed during the data collection period.

\section{Çocukluk Dönemi Yürütücü İşlevler Envanteri-Ebeveyn Formunun Okul Öncesi Dönem Çocukları İçin Geçerlik ve Güvenirlik Çalışması}

\author{
Beyza Hamamcı1 ${ }^{1}$, İbrahim Hakkı Acar ${ }^{2}$, Gülden Uyanık ${ }^{3}$
}

${ }^{1}$ Temel Eğitim Bölümü, Eğitim Fakültesi, Orta Doğu Teknik Üniversitesi, Ankara, Türkiye, beyza@metu.edu.tr

${ }^{2}$ Psikoloji Bölümü, Sosyal Bilimler Fakültesi, Özyeğin Üniversitesi, Istanbul, Türkiye, ibrahim.acar@ozyegin.edu.tr

${ }^{3}$ Temel Eğitim Bölümü, Atatürk Eğitim Fakültesi, Marmara Üniversitesi, İstanbul, Türkiye, guyanik@marmara.edu.tr

Sorumlu Yazar: Beyza Hamamcı

Makale Türü: Araştırma Makalesi

Bilgilendirme: Bu araştırma, 10 Ekim 2020 tarihinde "VIIth International Eurasian Educational Research Congress (EJER)" konferansında sunulmuştur.

Kaynak Gösterimi: Hamamcı, B., Acar, İ. H., \& Uyanık, G. (2021). The validity and reliability study of parent report of the childhood executive functioning inventory for preschoolers. Eğitimde Kuram ve Uygulama, 17(2), 1-10. doi: 10.17244/eku.884918

Etik Not: Araştırma ve yayın etiğine uyulmuştur. Bu çalışmada veriler 2020 yılı öncesi toplanmış olup, veri toplama sürecinde katılımcıların gönüllü katılımı gözetilmiştir. 


\title{
Validity and Reliability Study of Parent Report of the Childhood Executive Functioning Inventory for Preschoolers
}

\author{
Beyza Hamamc1 ${ }^{1}$, İbrahim Hakkı Acar², Gülden Uyanık ${ }^{3}$ \\ ${ }^{1}$ Department of Elementary and Early Childhood Education, Faculty of Education, Middle East Technical University, Ankara, \\ Turkey \\ beyza@metu.edu.tr, ORCID: 0000-0001-9926-4345 \\ ${ }^{2}$ Department of Psychology, Faculty of Social Sciences, Ozyegin University, Istanbul, Turkey \\ ibrahim.acar@ozyegin.edu.tr, ORCID:0000-0003-4007-5691 \\ ${ }^{3}$ Department of Primary Education, Ataturk Faculty of Eduaction, Marmara University, Istanbul, Turkey \\ guyanik@marmara.edu.tr, ORCID:0000-0001-9947-8159
}

\begin{tabular}{|c|c|}
\hline Abstract & Article Info \\
\hline $\begin{array}{l}\text { The present study aims to adapt the parent-report of the "Childhood Executive Functioning } \\
\text { Inventory (CHEXI)" into Turkish to use with preschool children. The CHEXI is a rating } \\
\text { instrument by which parents evaluate the executive functioning of children between ages of } 4 \\
\text { and } 12 \text { years. The sample of the present study consists of parents of } 212 \text { children attending } 37 \\
\text { public preschools during } 2019-2020 \text { academic year. Children's ages range from } 48 \text { to } 72 \\
\text { months. Parents completed the CHEXI, Children's Behavior Questionnaire-Short Form } \\
\text { (CBQ-SF), and Demographic Information Form. Results from the Confirmatory Factor } \\
\text { Analysis showed that the CHEXI has two factors aligned with the original structure; } \chi 2(250) \\
=383,275, \mathrm{CFI}=0.90, \mathrm{RMSEA}=0.05 \text { [ } 90 \% \text { CI } 04,06] \text {, SRMR=0.05. These dimensions are } \\
\text { Working Memory and Inhibitory Control. As a result of the item-level independent t-test } \\
\text { conducted for the upper and lower } 27 \% \text { groups, all items were significantly different between } \\
\text { groups. The internal reliability (Cronbach's Alpha) values of the inventory were found to } \\
\text { be } .90 \text { for the Working Memory and . } 78 \text { for the Inhibitory Control subscale. This was also } \\
\text { true for composite reliability. In addition, there was a significant correlation between CHEXI } \\
\text { and CBQ-SF's subscales, indicating criterion validity. The findings of the present study } \\
\text { suggest that CHEXI could be used with parents of preschool children in Turkey. }\end{array}$ & $\begin{array}{l}\text { Article History: } \\
\text { Received: } 22 \text { February } 2021 \\
\text { Revised: } 19 \text { June } 2021 \\
\text { Accepted: } 5 \text { July } 2021\end{array}$ \\
\hline
\end{tabular}

\section{Çocukluk Dönemi Yürütücü İşlevler Envanteri-Ebeveyn Formunun Okul Öncesi Dönem Çocukları İçin Geçerlik ve Güvenirlik Çalışması}

\begin{tabular}{|c|c|}
\hline Öz & Makale Bilgisi \\
\hline 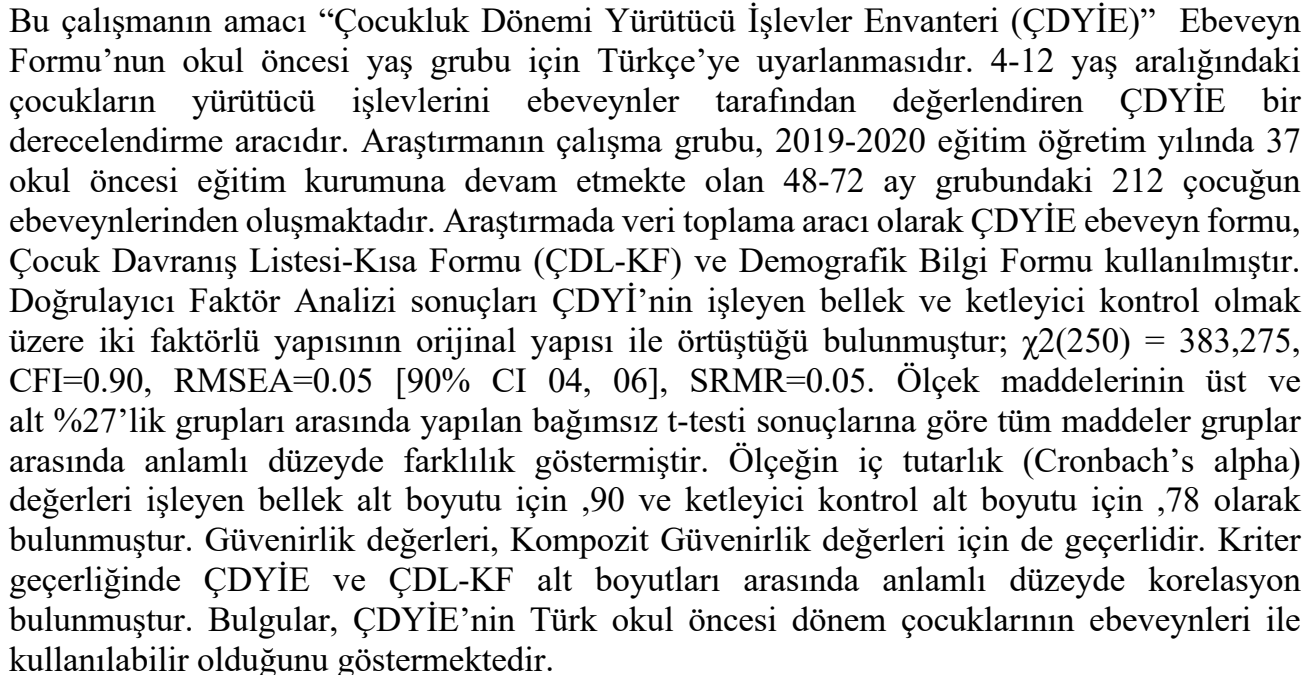 & $\begin{array}{l}\text { Makale Geçmişi: } \\
\text { Geliş: } 22 \text { Şubat } 2021 \\
\text { Düzeltme: } 19 \text { Haziran } 2021 \\
\text { Kabul: } 5 \text { Temmuz } 2021 \\
\text { Makale Türü: Araştırma } \\
\text { Makalesi }\end{array}$ \\
\hline
\end{tabular}




\section{Introduction}

Children display substantial improvements in all developmental domains during preschool years. Executive function (EF) is one of the important developmental domains that support children's concurrent and future social and academic outcomes. Executive function refers to an umbrella term for various cognitive processes that are at the center of goaldirected behaviors, thoughts, and emotions (Huizinga, Baeyens \& Burack, 2018). In the light of the relevant studies, the EF has been conceptualized with three components: inhibitory control, working memory, and mental flexibility (Lehto, Juujärvi, Kooistra \& Pulkkinen, 2003; Miyake et al., 2000). Inhibitory control entails the ability to suppress/prevent dominant thinking processes or actions that are not about the predetermined goal (Rothbart \& Posner, 1985). Working memory is a cognitive process to hold information and manipulate it in required situations (Baddeley, 1992). And, mental flexibility is the ability to change thoughts or actions according to the changing demands of a situation (Loftis, 2016). Miyake and colleagues (2000) found that each component of EF is independent and at the same time interrelated. For example, to utilize inhibitory control, children need working memory while knowing what should be inhibited and keeping their attention focused on a relevant task; and, in using mental flexibility, they need working memory and inhibitory control (Diamond, 2013).

The development of EF begins in early childhood and continues through adolescence in parallel with the development of the frontal lobe in the brain (Brown, 2002). Preschool years are considered as a period in which significant improvements take place in EF (Best \& Miller 2008; Garon, Bryson \& Smith, 2008). On that ground, the linear development of EF turns into a stable trajectory starting at the beginning of middle childhood; nevertheless, it slowly continues to develop later in the life (The Center on the Developing Child, 2020). In preschool years, EF is an important predictor of concurrent and future mathematics and literacy skills (Blair \& Razza, 2007; McCelland, Acock, Piccinin, Rhea \& Stallings, 2013; Ursache, Blair \& Raver, 2012).

The assessment of executive function in early childhood is important for researchers and educators who would like to understand how it develops as well as its contributions to children's learning and development. Historically, there has been an improvement in assessment of the EF. Progress has been made with the development of child-friendly tasks which are developmentally appropriate, drawing attention to ecological validity, increasing the sophistication and accuracy of statistical analyses, and the combination of neuropsychological and neurophysiological measurements (Hughes, 2011). Further, there are two major approaches to the assessment of the EF; performance-based assessment and ratings of EF. Performance-based assessment contains task-based tools that are employed by independent researchers with children in structured environments (e.g., lab). Ratings of EF refer to measures of the EF completed by adults (e.g. parent, teacher, etc.) to reflect their perceptions of the children's EF. Performance-based EF tasks are carried out in a quiet and well-prepared place with the least amount of distractions thus, they do not represent the home, school, and social environment of the child (Anderson, 2002). Although performance-based tasks are accepted as the standard way of measuring the cognitive skills of the child, executive function scales explain the behavioral performance of executive function skills in the context of everyday life (Gioia, Isquith, Guy \& Kenworthy, 2000). In this context, measuring tools that evaluate children's behavior through observations provide an advantage in obtaining information from the children's daily environment (home, school, etc.), thus providing a global understanding of the behavior (Nilsen, Huyder \& Liebermann, 2016).

Various inventories have been used for the executive functions: the observer's report (e.g., Behavior Rating Inventory of Executive Function [BRIEF (Gioia, Isquith, Guy \& Kenworthy, 2000)]; Childhood Executive Functioning Inventory [CHEXI (Thorell ve Nyberg, 2008)]; Comprehensive Executive Function Inventory [CEFI (Naglieri ve Goldstein, 2014)]). BRIEF is administered by parents and teachers to assess EF of children between the ages of 5-18 years. The inventory is an 86 item measuring tool; made of 8 sub-dimensions (suppression, set-shifting, emotional control, initiation, working memory, planning, regularity, and monitoring) and two comprehensive indexes (behavioral regulation and metacognition index). The CHEXI has parent and teacher reports of EF that is for children between the ages of 4-12. The inventory is a 26-item measuring tool that consists of two factors (inhibitory control and working memory). The CEFI is also parent and teacher reports of EF for children between the ages of 5-18. The inventory is a 100-item measuring tool consisting of nine sub-dimensions (attention, emotion regulation, flexibility, inhibitory control, initiation, organization, planning, self-monitoring, and working memory). Considering the utilization of the rating scales to assess children's EF, evaluating the psychometric properties of the CHEXI during the preschool years is important.

There has been a lack of studies in the Turkish context aiming to develop or adapt EF-based measures for preschool children (Taşkın-Gökçe \& Kandır, 2019). From this perspective, the present study focuses on the validity and reliability analyses of the CHEXI (Thorell \& Nyberg, 2008) with Turkish preschoolers. Thorell and Nyberg (2008), who were developers of the CHEXI, pointed out the necessity of a new inventory because other inventories' items had reflected symptoms of Attentional Deficit Disorders (ADHD), not the EF itself per se. For instance, the BRIEF as the most common inventory contains items reflecting ADHD symptoms, referring to impulsivity and attentional deficit 
defined in the Diagnostic and Statistical Manual of Mental Disorder (American Psychiatric Association, 1994). For this reason, Thorell and Nyberg (2008) developed the CHEXI to reflect the core aspects of the executive function: working memory and inhibitory control. In addition, it is important to employ developmentally appropriate measurement tools in assessing children's EF. On that ground, the purpose of the current study was to adapt parent-report of the CHEXI (Thorell \& Nyberg, 2008) with Turkish parents who had preschool-aged children.

\section{Method}

Research and publication ethics were followed. In this study, the data were collected before 2020, and voluntary participation of study group was observed during the data collection period.

\section{Sample Group}

The sample of this research consisted of the parents of 212 children attending preschool in 37 classes of 6 preschools affiliated to the Istanbul Provincial Directorate of National Education in the first semester of the 2019-2020 academic year. Children's ages were between 48 and 72 months $(\mathrm{M}=59.54$; $\mathrm{SD}=6.85)$. Of these children, 100 were girls $(47.2 \%)$ and 112 were boys $(52.8 \%)$. The percentages of children's attendance years to preschool education was one year for $37.7 \%(\mathrm{n}=80)$, two years for $45.3 \%(\mathrm{n}=96)$, three years for $13.7 \%(\mathrm{n}=29)$, and $3.3 \%$ were missing. In considering the mother's data; their ages were between 22 to $73(\mathrm{M}=35,60 ; \mathrm{SD}=5,76) ; 72$ mothers $(34 \%)$ had educational degrees between primary school and high school, 138 mothers $(65.1 \%)$ had bachelor and graduate degrees and two mothers' (9\%) answers were missing. 77 mothers (36.3\%) reported as working full-time, 24 mothers $(11.3 \%)$ reported as working part-time, 106 mothers (50\%) did not work, and five mothers' (2.4\%) answers were missing. Regarding of fathers' data; their ages were between 26 to 64 ages $(M=38.27 ; \mathrm{SD}=5.30)$; 93 fathers $(43.9 \%)$ had between primary school and high school degrees, 114 fathers $(53.7 \%)$ had between bachelor and postgraduate degrees, and five fathers' $(2.4 \%)$ answers were missing. 195 fathers (92\%) reported as working full-time, eight fathers (3.8\%) reported as working part-time, two fathers $(9 \%)$ did not work, and seven fathers' (3.3\%) answers were missing. Considering family's total income; 50 families (23.6\%) had to earn between $4000 \mathrm{TL}$ and below, 115 families (54.3\%) had to earn between 4001 and 10000 , 29 families (13.6\%) had to earn $10001 \mathrm{TL}$ and above and finally, 18 families' (8.5\%) answers were missing. The SES variable was calculated by averaging $\mathrm{z}$ scores of parental education level and the family's total income.

\section{Data Collection Tools}

\section{Parent and Child Information Form}

The demographic information form was used in the study compromised of 15 questions pertaining to information about the children, the mother, and the father. In this form, there were questions about the child to obtain information regarding child's age, gender, attendance years to preschool education, development, and health-related questions and questions to determine regular medication taken by the child. Regarding the parents, the questions were asked to determine their age, level of education, employment status, and income status. The form was filled out by the parents.

\section{Childhood Executive Functioning Inventory}

The 5-point Likert-type scale was developed by Thorell and Nyberg (2008) entitled "The Childhood Executive Functioning Inventory (CHEXI)" to evaluate the executive function skills of children by teachers and parents (1: "Definitely not true", 5: "Definitely true") (see Appendix-A to sample items). This inventory consists of 26 items and two factors (working memory and inhibitory control). The test-retest reliability coefficient of the original scale was 0.89 , while it was 0.86 for the inhibitory control and .75 for the working memory.

\section{Adaptation Study of the Childhood Executive Functioning Inventory into Turkish}

Thorell and Nyberg's (2008) study showed that as a result of the factor analysis of parent form, there were two factors (working memory and inhibitory control). Test-retest reliability for parent evaluations was found to be .89. However, the correlation values of laboratory measurements and CHEXI parental assessment were found to be between .26 and .33. The correlation values of the CHEXI parental assessment with the symptoms of Attention Deficit Hyperactivity Disorder were found to be ranging from .26 to .36 . Finally, the correlation values of CHEXI parental assessment with early academic skills were found to be between -.41 and -.16.

Turkish adaptation of the CHEXI was conducted by Kayhan (2010) with 134 children's parents and teachers. Children's ages were between 70 months and 100 months, with a mean age of 83 months. The results of Kayhan's (2010) study; test-retest reliability value of the parent-reported whole scale was .89. It was found that the two-factor structure of the inventory explained $67 \%$ of the variances and the correlation values between the two factors in the 
teacher-report were .69. Although the CHEXI was developed for children aging between 4 to 12, the adaptation study did not involve children who were 48-69 months. The teacher form of CHEXI for children covering the period of 4872 months was studied by Arslan-Çiftçi, Uyanık, and Acar (2020) based on the items adapted by Kayhan (2010). In the study, by removing the 25th and 26th items from the 26-item form adapted by Kayhan (2010), a 24-item form was obtained by preserving its two-factor structure. In Arslan-Çiftçi and colleagues' (2020) adaptation study of the inventory with teachers, the reliability was found to be .95 for the working memory and .89 for the inhibitory control, while the test-retest reliability values were found to be .89 for working memory and .85 for the inhibitory control.

In the present study, we used the teacher-report version that was adapted by Arslan-Çiftçi and colleagues (2020) with parents.

\section{Children's Behavior Questionnaire - Short Form}

The 7-point Likert-type scale was developed by Putnam and Rothbart (2006) with the title of "Children's Behavior Questionnaire (CBQ-SF)" to measure the temperamental characteristics of children (1: "Extremely untrue of your child" 7: "Extremely true of your child") and has 94 items and 15 sub-dimensions (activity level, anger/frustration, approach/positive participation, attentional focusing, discomfort, falling reactivity/soothability, fear, high-intensity pleasure, impulsivity, inhibitory control, lack shyness, low-intensity pleasure, perceptual sensitivity, sadness and smiling). In the internal consistency analysis of the original scale, the reliability coefficients obtained from the subdimensions of the scale are .65 and above. Although internal consistency may appear low, it has been shown to be accepted value for internal reliability (Hair et al., 2014). The adaptation study of the measurement tool to Turkish was conducted by Akın Sarı, İşeri, Yalçın, Akın Aslan, and Şener (2012). For the purpose of the present study, we used attentional focusing and inhibitory control subscales. It was found that the internal consistency coefficient values for the inhibitory control and attentional focusing were .75 and .72, respectively in the original study (Putnam \& Rothbart, 2006). Akın Sar1 and colleagues (2012) found internal consistency of .63 for attentional focusing and .67 for inhibitory control in Turkish version of the scale. With the present sample, the reliability values were found as .63 for attentional focusing and .69 for inhibitory control.

\section{Data Collection Procedures}

Once the school administration approved the study protocol, we contacted teachers and parents to ask for their consent. As a next step, the forms and data collection tools were given to parents by the teachers. Consented parents completed forms and returned their completed forms to the researcher.

\section{Data Analysis}

SPSS 21 and Mplus 7.4 (Muthén \& Muthén, 2012) were used to analyze the data. The Confirmatory Factor Analysis (CFA) was used to test whether the scale structure revealed by Thorell and Nyberg (2008) was also valid with Turkish parents. The CFA is utilized to determine the fitting of a structured measure with a new sample (Harrington, 2008). Before moving into CFA analysis, we tested the multivariate normality assumptions by using the criteria of skewness of \pm 3and kurtosis of \pm 7 (Kline, 2005). In addition, we utilized restricted maximum likelihood estimator in our CFA models, which has been shown to be providing accurate results in the presence of nonnormality (Li, 2015).

Comparative Fit Index (CFI; Bentler, 1995), Root Mean Square Error of Approximation (RMSEA; Browne \& Cudeck, 1992), and Standardized Root Mean Square Residual (SRMR; Bentler, 1995; Hu \& Bentler, 1999) model fit indices were used to test the fit of the CFA model with the current data. RMSEA values lower than 0.08 are considered to be acceptable (Brown \& Cudeck, 1992; MacCallum, Browne \& Sugawara, 1996). CFI values are above 0.9 constitutes an acceptable fit index (Çokluk, Şekercioğlu \& Büyüköztürk, 2012; Kline, 2005; Marsh, Balla \& McDonald, 1988).

The correlations between the sub-dimensions and the differences between the upper $27 \%$ and lower $27 \%$ groups were calculated with the independent samples t-test. In addition, the CBQ-SF (Akın Sarı et al., 2012) was used for criterion validity. The internal reliability of the scale was calculated with Cronbach's Alpha and Composite Reliability (Raykov, 1997) methods.

\section{Findings}

Table 1. Results from Confirmatory Factor Analysis, Reliability, and Lower-Upper Group Differences

\begin{tabular}{ccccccccc}
\hline & & Lower 27\% & \multicolumn{3}{c}{ Upper 27\% } \\
\hline $\begin{array}{c}\text { CFA } \\
\text { loadings } \\
(\mathrm{N}=212)\end{array}$ & $\begin{array}{c}\text { Total Item } \\
\text { Correlation } \\
(\mathrm{n}=191)\end{array}$ & $\mathrm{n}$ & $\mathrm{M}$ & $\mathrm{SD}$ & $\mathrm{n}$ & $\mathrm{M}$ & $\mathrm{SD}$ & $\mathrm{t}$ \\
\hline
\end{tabular}




\begin{tabular}{|c|c|c|c|c|c|c|c|c|c|}
\hline $\begin{array}{l}\text { Working } \\
\text { Memory }\end{array}$ & $\alpha=, 90$ & & 59 & 1,25 &, 16 & 58 & 2,67 & ,44 & $-22,96 * *$ \\
\hline & $\mathrm{CR}=, 90$ & & & & & & & & \\
\hline Item 1 &, 62 & ,59 & 58 & 1,08 &, 28 & 58 & 3,44 & ,68 & $-24,42 * *$ \\
\hline Item 3 &, 59 &, 57 & 57 & 1,00 &, 00 & 58 & 2,27 & ,64 & $-14,97 * *$ \\
\hline Item 6 &, 63 &, 60 & 57 & 1,03 &, 18 & 58 & 3,44 &, 65 & $-28,98 * *$ \\
\hline Item 7 &, 62 &, 59 & 56 & 1,12 &, 33 & 58 & 3,31 &, 62 & $-23,10 * *$ \\
\hline Item 9 & ,49 &, 52 & 58 & 1,00 &, 00 & 58 & 2,39 &, 79 & $-13,40 * *$ \\
\hline Item 12 & ,51 & ,52 & 57 & 1,00 &, 00 & 58 & 3,22 &, 62 & $-27,44 * *$ \\
\hline Item 14 & ,59 &, 58 & 58 & 1,01 &, 13 & 58 & 3,55 & 62 & $-30,17^{* *}$ \\
\hline Item 17 & ,64 &, 62 & 58 & 1,00 &, 00 & 58 & 2,69 &, 77 & $-16,56^{* *}$ \\
\hline Item 19 &, 67 &, 64 & 58 & 1,00 &, 00 & 58 & 2,69 &, 68 & $-18,90 * *$ \\
\hline Item 20 &, 77 &, 74 & 57 & 1,00 & 00 & 58 & 3,06 &, 72 & $-21,62 * *$ \\
\hline Item 21 &, 68 &, 64 & 55 & 1,00 &, 00 & 58 & 3,22 &, 46 & $-35,81^{* *}$ \\
\hline Item 23 &, 59 &, 54 & 49 & 1,00 &, 00 & 58 & 3,34 & 64 & $-25,76^{* *}$ \\
\hline Item 24 &, 76 &, 75 & 58 & 1,00 &, 00 & 58 & 3,24 &, 54 & $-31,61 * *$ \\
\hline \multirow[t]{2}{*}{$\begin{array}{l}\text { Inhibitory } \\
\text { Control } \\
\end{array}$} & $\alpha=.78$ & & 59 & 2,02 &, 34 & 58 & 3,48 & ,40 & $-21,01 * *$ \\
\hline & $\mathrm{CR}=, 80$ & & & & & & & & \\
\hline Item 2 &, 27 & ,22 & 57 & 1,68 &, 46 & 58 & 4,37 & 48 & $-30,14 * *$ \\
\hline Item 4 & ,62 &, 52 & 58 & 1,12 &, 32 & 58 & 3,74 &, 66 & $-26,94 * *$ \\
\hline Item 5 & ,49 &, 43 & 58 & 1,48 &, 50 & 58 & 3,72 &, 67 & $-20,35^{* *}$ \\
\hline Item 8 & ,58 & ,46 & 59 & 1,59 &, 49 & 58 & 3,89 &, 72 & $-20,22 * *$ \\
\hline Item 10 &, 27 &, 22 & 59 & 2,05 &, 75 & 58 & 4,98 &, 13 & $-29,23 * *$ \\
\hline Item 11 &, 54 & ,49 & 58 & 2,19 &, 75 & 58 & 4,48 &, 50 & $-19,15^{* *}$ \\
\hline Item 13 &, 55 &, 47 & 58 & 1,01 &, 13 & 58 & 3,50 &, 65 & $-28,27 * *$ \\
\hline Item 15 & ,64 &, 55 & 59 & 1,62 &, 48 & 58 & 4,41 &, 49 & $-30,61 * *$ \\
\hline Item 16 &, 62 &, 53 & 54 & 1,00 & 00 & 54 & 3,50 & 60 & $-30,28^{* *}$ \\
\hline Item 18 &, 63 &, 55 & 58 & 1,50 &, 50 & 58 & 4,25 &, 51 & $-29,14^{* *}$ \\
\hline Item 22 &, 49 &, 39 & 57 & 1,00 & 00 & 58 & 3,34 & 63 & $-27,80 * *$ \\
\hline
\end{tabular}

$* * p<001 . \mathrm{CR}=$ Composite Reliability

Considering the model fit indices, it was found that this model fit well with the data $(\chi 2(250)=383,275$, $\mathrm{CFI}=0.90, \mathrm{RMSEA}=0.05$ [90\% CI 04, 06], SRMR=0.05). Factor loadings were significant (see. Table 1). In addition, the internal consistency values of the factors in the current study are $\alpha=.90(\mathrm{CR}=, 90)$ for Working Memory and $\alpha=.78$ $(\mathrm{CR}=, 80)$ for Inhibitory Control. Further, we examined the lower and upper $27 \%$ group differences for each item and sub-dimensions. As shown in Table 1, significant differences have been found between the lower and upper groups at both the item and sub-dimension levels.

Table 2. Correlation values between the CHEXI subscales, criterion measures, and demographic variables

\begin{tabular}{|c|c|c|c|c|c|c|c|}
\hline & & 1 & 2 & 3 & 4 & 5 & 6 \\
\hline \multirow{2}{*}{ CHEXI } & $\begin{array}{l}\text { 1. Working } \\
\text { Memory }\end{array}$ & - & & & & & \\
\hline & $\begin{array}{l}\text { 2. Inhibitory } \\
\text { Control }\end{array}$ &, $547 * *$ & - & & & & \\
\hline \multirow{5}{*}{ CBQ-SF } & $\begin{array}{l}\text { 3. Attentional } \\
\text { Focusing }\end{array}$ &, $353 * *$ &, $438 * *$ & - & & & \\
\hline & $\begin{array}{l}\text { 4. Inhibitory } \\
\text { Control }\end{array}$ &, $246^{* *}$ &, $333 * *$ &, $454 * *$ & - & & \\
\hline & 5. Child Sex &, 006 &,- 068 &,$- 152 *$ &,- 077 & - & \\
\hline & 6. Child Age & ,206 &,- 060 &, $220 * *$ &, $170^{*}$ &, 075 & - \\
\hline & 7. Family SES &, 052 &, 112 &, $163 *$ & ,029 &,- 076 &,- 007 \\
\hline
\end{tabular}


Note: CHEXI: Childhood Executive Function Inventory. CBQ-SF: Children's Behavior Questionnaire-Short Form. SES: Socioeconomic Status. Child Sex (1= Girls, $2=$ Boys). ${ }^{*} p<, 05 ; * * p<, 001$

As seen in Table 2, the CHEXI's subscales significantly and positively correlated with the CBQ's subscales, indicating criterion validity. In detail, working memory was significantly correlated with attentional focusing $(r=, 547$; $\mathrm{p}<, 001)$ and inhibitory control $(\mathrm{r}=, 246 ; \mathrm{p}<, 001)$ of the CBQ. Inhibitory control of the CHEXI was significantly correlated with attentional focusing $(r=, 438 ; p<, 001)$ and inhibitory control $(r=, 333 ; p<, 001)$ of the CBQ. See Table 2 for details.

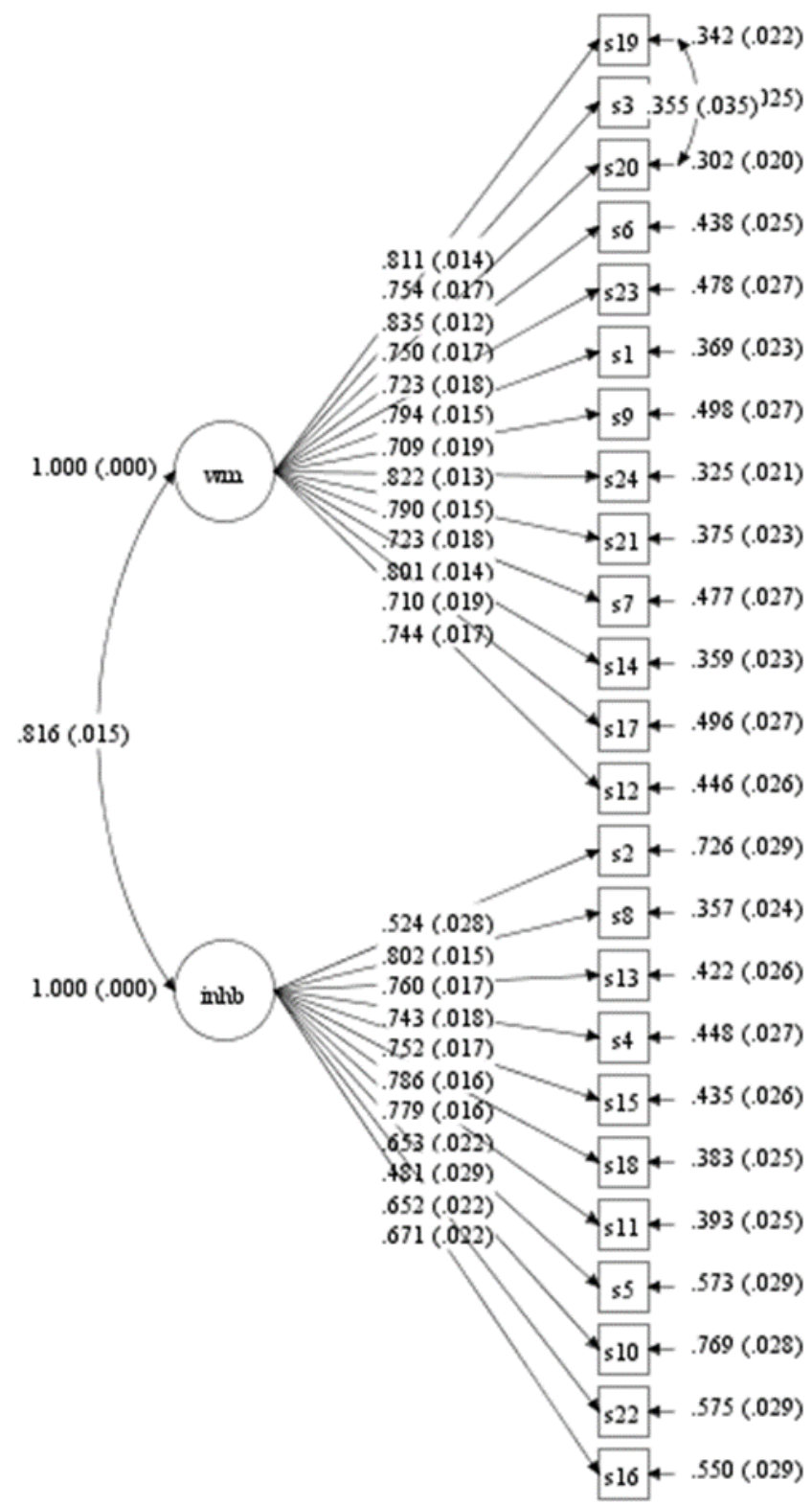

Figure 1. Diagram for the Confirmatory Factor Analyses. WM= Working Memory. INHB= Inhibitory Control

\section{Discussion and Conclusion}

The purpose of the present study was to examine the reliability and validity of the parent-report of the CHEXI for preschool-aged children (Thorell \& Nyberg, 2008). Results from the analyses showed that the two-factor structure of the CHEXI was aligned within the current data. We also found that all items and subscales (working memory and inhibitory control) were distinct between lower and upper groups of the sample. The reason behind this finding could be explained by the fact that the items of the "Childhood Executive Functioning Inventory" show the distinctive feature of the child's executive functions skills. Further, there was a significant correlation between subscales of the CHEXI and CBQ, indicating confirmation of the criterion validity of the scale. This clearly shows that parents' perception of 
children's temperamental effortful control is related to parent-report of EF. This could be explained by the notion that children's temperamental regulation could be subcomponent or collaborative construct of the EF (Simonds, Kieras, Rueda, \& Rothbart, 2007). Internal consistency values of each subscale were acceptable. Also, the indicates that the items of the measure represent the defined conceptualization of the constructs.

In the present study, we found that as children got older, their EF levels reported by parents were higher. This finding was consistent with the previous research (Best \& Miller, 2010; Garon, Bryson, \& Smith, 2008), showing that children's EF increases as children get older. This could be due to improvements in children's behavioral control and cognitive skills scaffolding children's EF (Ball et al., 2011). Also, parents reported girls having higher levels of attentional focusing than did boys. Sex differences in EF could be explained from the perspective of biological underlying such that girls are less impulsive, avoid negative outcomes, and have improved working memory (Grissom \& Reyes, 2019). And considering the results of SES, there was a positive relationship with the EF. The reason behind this finding could suggest that children within high SES family context could have more resources to practice EF (Howard et al., 2019; Sarsour et al., 2011).

The preschool period is an important developmental stage for development of the EF (Best \& Miller, 2010; Garon, Bryson \& Smith, 2008). Researchers have drawn attention to the advantageous and disadvantageous aspects of the measurement tools of the EF (Anderson, 2002; Gioia, Isquith, Guy \& Kenworthy, 2000; Nilsen, Huyder \& Liebermann, 2016). In general, the discussion rolls around whether performance-based and parent/teacher reports evaluate the similar or same aspects of the EF, and it has shown that there are discrepancies between the two types of measures (Acar, Frohn, Prokasky, Molfese \& Bates, 2019; Toplak, West \& Stanovich, 2013). On that ground, it is important to utilize diverse measures to assess children's EF to comprehend a broader picture regarding their EF skills. By doing so, we could have a better understanding regarding the EF as related to children's social and academic skills (Blair, 2002; Blair \& Razza, 2007; Hughes \& Ensor, 2007). Overall, the currently validated measure can be utilized in future research and practice that have an interest in assessing children's EF.

All authors contributed to the manuscript equally.

\section{Contributions of the Researchers}

\section{Financial Support and Acknowledgment}

The authors declared that this research received no specific grant from any funding agency in the public, commercial, or not-for-profit sectors. Authors would like to thank Dr. Hande Arslan-Çiftçi from Istanbul Medeniyet University for her permission and kindly help.

\section{Conflict of Interest}

The authors have disclosed no conflict of interest.

\section{References}

Acar, İ. H., Frohn, S., Prokasky, A., Molfese, V. J. \& Bates, J. E. (2019). Examining the associations between performance based and ratings of focused attention in toddlers: Are we measuring the same constructs? Infant and Child Development, 28(1), e2116. doi: 10.1002/icd.2116

Akın Sarı, B., İşeri, E., Yalçın, Ö., Akın Aslan, A. \& Şener, Ş. (2012). Çocuk davranış listesi kısa formunun türkçe güvenilirlik çalışması ve geçerliliğine ilişkin ön çalışma. Klinik Psikiyatri Dergisi, 15(3), 135-143.

Anderson, P. (2002). Assessment and development of executive function (ef) during childhood. Child Neuropsychology, 8(2), 71-82. doi: 10.1076/chin.8.2.71.8724

American Psychiatric Association. (1994). Diagnostic and statistical manual of mental disorders (4 ${ }^{\text {th }}$ edition). Washington, DC: Author.

Arslan-Çiftçi, H., Uyanık, G. \& Acar, İ.H. (2020). Çocukluk dönemi yürütücü işlevler envanteri türkçe formunun 4872 aylık çocuklar için geçerlik ve güvenirlik çalışması. Erken Çocukluk Çalışmaları Dergisi, 4(3), 762-787

Baddeley, A. (1992). Working memory. Science, 225(5044), 556-559. doi:10.1126/science.1736359 
Ball, G., Stokes, P. R., Rhodes, R. A., Bose, S. K., Rezek, I., Wink, A.-M., . . Turkheimer, F. E. (2011). Executive functions and prefrontal cortex: A matter of persistence? Frontiers in Systems Neuroscience, 5(3), 1-13. doi: $10.3389 /$ fnsys.2011.00003

Best, J. R. \& Miller, P. H. (2010). A developmental perspective on executive function. Child Development, 81(6), 1641 1660. doi: 10.1111/j.1467-8624.2010.01499.x

Blair, C. (2002). School readiness: Integrating cognition and emotion in a neurobiological conceptualization of children's functioning at school entry. American Psychologist, 57, 111-127. doi: 10.1037/0003-066X.57.2.111

Blair, C. \& Razza, R. P. (2007). Relating effortful control, executive function, and false belief understanding to emerging math and literacy ability in kindergarten. Child Development, 78(2), 647-663. doi: 10.1111/j.14678624.2007.01019.x

Brown, T. E. (2002). DSM-IV: ADHD and executive function impairments. Advanced Studies in Medicine, 2(25), 910914.

Diamond, A. (2013). Executive functions. Annual Reviews of Psychology, 64, 135-168. doi: 10.1146/annurev-psych$113011-143750$

Garon, N., Bryson, S. E. \& Smith, I. M. (2008). Executive function in preschoolers: A review using an integrative framework. Psychological Bulletin, 134(1), 31-60. doi: 10.1037/0033-2909.134.1.31

Gioia, G. A., Isquith, P. K., Guy, S. C. \& Kenworthy, L. (2000). Behavior rating inventory of executive function. Lutz: Psychological Assessment Resources.

Grissom, N. M., \& Reyes, T. M. (2019). Let's call the whole thing off: evaluating gender and sex differences in executive function. Neuropsychopharmacology, 44, 1-11. doi: 10.1038/s41386-018-0179-5

Hair Jr., J. F., Black, W. C., Babin, B. J. ve Anderson, R. E. (2014). Multivariate data analysis (7. basım). London: Pearson Education Limited.

Harrington, D. (2008). Confirmatory factor analysis. New York: Oxford University Press.

Howard, S. J., Cook, C. J., Everts, L., Melhuish, E., Scerif, G., Norris, S., . . Draper, C. E. (2019). Challenging socioeconomic status: A cross-cultural comparison of early executive function. Developmental Science, 23(1), 1-9. doi: $10.1111 /$ desc. 12854

Hughes, C. (2011). Changes and challenges in 20 years of research into the development of executive functions. Infant and Child Development, 20, 251-271. doi:10.1002/icd.736

Hughes, C. \& Ensor, R. (2007). Executive function and theory of mind: Predictives relations from ages 2 to 4. Developmental Psychology, 43(6), 1447-1459. doi: 10.1037/0012-1649.43.6.1447

Huizinga, M., Baeyens, D. \& Burack, J. A. (2018). Executive function and education. Lausanne: Frontiers Media. doi:10.3389/978-2-88945-572-0

IBM Corp. Released 2012. IBM SPSS Statistics for Windows, Version 21.0. Armonk, NY: IBM Corp.

Kayhan, E. (2010). A validation study for the childhood executive functioning inventory: Behavioral correlates of executive functioning. (Yayınlanmamış yüksek lisans tezi). Sosyal Bilimler Enstitüsü, Boğaziçi Üniversitesi İstanbul.

Kline, R. B. (2005). Principles and practice of structural equation modeling (2nd ed.). Guilford Press. 
Lehto, J. E., Juujärvi, P., Kooistra, L., \& Pulkkinen, L. (2003). Dimensions of executive functioning: Evidence from children. British Journal of Developmental Psychology, 21(1), 59-80. doi: 10.1348/026151003321164627

Li, C.-H. (2015). Confirmatory factor analysis with ordinal data: Comparing robust maximum likelihood and diagonally weighted least squares. Behavior Research Methods, 48(3), 936-949. doi:10.3758/s13428-015-0619-7

Loftis, C. (2016). Mental flexibility. J. Kreutzer, J. DeLuca \& B. Caplan içinde, Encyclopedia of Clinical Neuropsychology. Springer, Cham. doi:10.1007/978-3-319-56782-2_2123-2

McCelland, M. M., Acock, A. C., Piccinin, A., Rhea, S. A. \& Stallings, M. C. (2013). Relations between preschool attention span-persistence and age 25 educational outcomes. Early Childhood Research Quarterly, 28(2), 314324. doi: $10.1016 /$ j.ecresq.2012.07.008

Miyake, A., Friedman, N. P., Emerson, M. J., Witzki, A. H., Howerter, A. \& Wager, T. D. (2000). The unity and diversity of executive functions and their contributions to complex "frontal lobe" tasks: A latent variable analysis. Cognitive Psychology, 41(1), 49-100. doi: 10.1006/cogp.1999.0734

Muthén, L. K., \& Muthén, B. O. (2012). Mplus user’s guide. Los Angeles, CA: Muthén \& Muthén.

Naglieri, J. A. \& Goldstein, S. (2014). Using the Comprehensive Executive Function Inventory (CEFI) to assess executive function: From theory to application. In J. A. Naglierive S. Goldstein, Handbook of Executive Functioning (pp. 223-244). New York: Springer.

Nilsen, E. S., Huyder, V. \& Liebermann, D. (2016). Ratings of everyday executive functioning (REEF): A parent-report measure of preschoolers' executive functioning skills. Psychological Assessment, 29(1), 50-64. doi: $10.1037 /$ pas0000308

Putnam, S. P. \& Rothbart, M. K. (2006). Development of short and very short forms of the Children's Behavior Questionnaire. Journal of Personality Assessment, 87(1), 102-112. doi: 10.1207/s15327752jpa8701_09

Rothbart, M. K. \& Posner, M. I. (1985). Temperament and the development of self-regulation. L. C. Hartlageve C. F. Telzrow içinde, The neuropsychology of individual differences: A developmental perspective (s. 93-123). Boston: Springer.

Sarsour, K., Sheridan, M., Jutte, D., Nuru-Jeter, A., Hinshaw, S., \& Boyce, W. T. (2011). Family socioeconomic statius and child executive functions: The roles of language, home environment, and single parenthood. Journal of the International Neuropsychological Society, 17, 120-132. doi:10.1017/S1355617710001335

Simonds, J., Kieras, J., Rueda, M., \& Rothbart, M. (2007). Effortful control, executive attention, and emotional regulation in 7-10-year old children. Cognitive Development, 22(4), 474-488. doi:10.1016/j.cogdev.2007.08.009.

Taşkın-Gökçe, T. G., \& Kandır, A. (2019). Erken çocukluk döneminde yönetici işlevlerin gelişimi ve değerlendirilmesi ile ilgili Türkiye'de yapılan bilimsel çalışmaların incelenmesi. Afyon Kocatepe Üniversitesi Sosyal Bilimler Dergisi, 21(2), 529-546. doi: 10.32709/akusosbil.474618

The Center on the Developing Child. (2020, Nisan 28). Executive function \& self-regulation. https://developingchild.harvard.edu/science/key-concepts/executive-function/ adresinden alınd1

Thorell, L. B. \& Nyberg, L. (2008). The childhood executive functioning inventory (chex1): A new rating instrument for parents and teachers. Developmental Neuropsychology, 33(4), 536-552. doi: 10.1080/87565640802101516

Toplak, M. E., West, R. F. \& Stanovich, K. E. (2013). Practitioner review: Do performance-based measures and ratings of executive function assess the same construct? The Journal of Child Psychology and Psychiatry, 54(2), 131143. doi: $10.1111 /$ jcpp. 12001 
Ursache, A., Blair, C. \& Raver, C. C. (2012). The promotion of self-regulation as a means of enhancing school readiness and early achievement in children at risk for school failure. Child Development Perspectives, 6(2), 122-128. doi: 10.1111/j.1750-8606.2011.00209.x 